\title{
Social Research
}

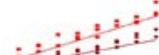

i:i:

1.2 .2
-1

\section{International Journal of Social Research (ISSN:2576-5531)}

\section{Contradictions in Christianity}

\section{Kuang-ming Wu}

\begin{abstract}
The traditional Christianity shows itself full of contradictions when we casually look into it. Is it itself cracked to begin with? Upon reflection, we realize that its contradictions actually show how much beyond all our human wits and logic the Beyond-all is.

This realization clues us into looking again, and Christianity then reveals itself with many levels of depths of love and justice in God our Creator. This paper instantiates some of these stunning revelations unnoticed before.
\end{abstract}

Keywords: contradictions, love, justice, actuality
*Correspondence to Author:

Kuang-ming Wu

kmwu2002@yahoo.com

How to cite this article:

Kuang-ming Wu.Contradictions in Christianity. International Journal of Social Research, 2017; 1:8.

\section{eSciencePublisher}

eSciPub LLC, Houston, TX USA. Website: http://escipub.com/ 
We are amazed. The innocent-looking traditional Christianity shows itself as full of contradictions when we casually look into it. Is it itself cracked to begin with? Upon reflection, we realize that its contradictions actually show how much beyond all our human wits and logic the Beyond-all is. This realization clues us into looking again, and Christianity then reveals itself with many levels of depths of love and justice in God our Creator. This paper instantiates some of these stunning revelations unnoticed before.

\section{\#Born to Ultimate:}

We are born to pursue knowing things to their ultimate. This is how sciences of all sorts are born. Pursuit to the ultimate is religious. We are born religious, and science is our religious pursuit. Buddhism is a science that tells us on how to rid us of our headaches of living. This science tells us to rid us of our head to cure headache. This is because our headache comes from our illusion in head-ignorance that all is vanity of all vanities. And so ridding us of our root head-ignorance cures our headache at the root. And then, as we try to cut our head to cure our headache, we shall find that there is no head to cut in the first place. Thus this science of Buddhism is totally consistent, delightfully without contradiction.

This science of Buddhism has one thing amiss, however. It lacks information on wherefrom our ignorance comes. Buddhism is rootless as it lacks in the ultimate origin of things and of itself. And so, it keeps dangling in midair of consistency. The pragmatic science of Buddhism is not religious enough. IWe must turn to another scientific religion called "Christianity" for the ultimate root and origin of things. It turns out that Christianity does give us the ultimate origin of all things, but then this Christianity is inconsistent, filled with contradictions so fascinating. We must pursue its contradictions as to what they are and what they mean.

\section{\#Contradictions in Christianity:}

Amazingly, Christianity abounds in contradictions everywhere. The Christians believe that God our Beyond-all must have created the world. It is because nothing comes from nothing but must have come from elsewhere. And so, whatever things that exist must have been created by almighty God. But "creation" is a contradiction, because "God" has no beginning and no end, whereas the world has its beginning and its end. And so, the beginning-less endless has initiated things with beginning and end. Creation is a cosmic contradiction. Existence owes to an enormous contradiction.

"How could we and things have come from a contradiction?" We ask, and Christianity would answer, "Because love creates, and God is love." But then, "God is love" is itself a contradiction, in that God is the least likely to be affected, while love is the most likely to be affected. So, "God is love" is "The least likely to be affected is the most likely to be affected," which is a straight contradiction, as the ancient Stoics claimed. Our very existence is harvested by a contradiction (creation) out of contradiction (God as love).

Now a whole host of contradictions quite amazing come out from the above two basic contradictions of creation and love. The Christian Incarnation is God's second creation in love, in which God-not-human becomes the human-not-God. Jesus as God-man is a straight contradiction. Worse yet, in God's love-creation, this world created by love almighty is full of destructive violence in hatred.

Someone may respond, saying that love allows freedom to choose, and violence in hate is resulted from misuse of freedom, as we humanity mistakenly have chosen hatred in violence. We then must ask back on why the almighty love has not created freedom that is free to choose love alone and nothing else. Love in its all-power must have been able to do so, so we would think. 
Violence in hatred is $\sin .^{1}$ Christ is said to be tempted in all things as we are, yet without sin. And then the Bible said that Christ became sin (to die for us). What is going on here on sin and Christ? Is Christ related to sin, or is he not? He cannot be both related and not-related to sin, now can he? Love almighty seems to tend to embrace such irreconcilable contradiction.

In Matthew 5, Jesus said that he came to fulfill all laws to their letters, and then he went ahead to command us to do things all-different and even opposed to the laws.

He culminates the whole bit by enjoining us to love our enemies who we are to hate. Hate joins love here, which is contradictory. $\mathrm{He}$ wants us to turn the other cheek, and later when a soldier hit him on the cheek, he did not turn his other cheek but protested.

$\mathrm{He}$ is extraordinary in being wise and clever as shown in all his debates with most of the cleverest scholars then, and yet he claimed that the whole Kingdom of God belongs to immature children who know nothing. He claimed he brings the sword, not peace, and yet all his words of comfort to us are constant assurance of peace. Discipleship of Jesus for our peace is yet enormously costly. All his disciples died painful deaths in violence. What is going on in following Jesus? Are we to follow Jesus for peace or for pain?

His Resurrection is his glorious fulfillment of his death on the cross. But his Resurrection came not as the loud culmination of his task on the terrific cross no less loudly and widely advertised, but as a hushed private "Peace to you!" here and there, almost as an appendix in stealth. Is the remarkable world-shaking Resurrection a fulfillment as an appendix? That does not make sense, does it? Contradictions abound in Christianity all over, indeed.

One possible meaning of such incredible contradictions in Christianity must be that the

\footnotetext{
${ }^{1}$ All cumbersome references in the Bible are omitted, to ensure
} the smooth going of the description here.
Good News of Christianity is too good to be true and too much sensible to our limited mind of feeble human thinking as to appear as nonsense. The Beyond-all of Divinity is so beyond us humans as to appear as our logical contradictions. When contradictions appear with logical disasters, we must lift up our heads, for our salvation draws near with our realization of the divine good as contradictory to our reasonable expectations human, all too human.

The Beyond is a gigantic meteorite that hits our sense and sensibility into scattered pieces of contradictions. We human are whammed stunned into silence. One way to describe these scattered pieces is to see how contradictory Christianity is. God the infinitely powerful is all-Yang. This Yang-God acts on us in a completely Yin-way. Yang-God allpowerful is born into a Yin-baby all-powerless, for humble us to parent and care for. And then he grows up to Yin-accept Yin-death on the cross.

At death, he mumbled, "It is finished (completed)." How could Yang-completion be death Yin-vanishing? His rising-up again into life glorious all-Yang is shown Yin-stealthily in private, never publicly displayed. Such glorious Yang-resurrection is identified as Yin-hushed as if it were a Yin-appendix to Yin-death. Following such Jesus is enormously Yin-costly, as all his disciples through history died violent Yin-deaths.

God is love, indeed, as Yang-God is tender Yinlove, as Yin-Yang opposites are identical here in the Beyond, ever. Such contradictory nonsense is totally beyond us human, to compose the Good News beyond this world. But then, this Divine Good News of love beyond us carries with it commands to us to love and care for our neighbors we usually could not care less about.

\section{\#Baby-Needs Command Care:}

"Our neighbors are now our baby-gods whose helpless needs command us to serve them to 
help them grow in joys of becoming themselves." This statement is innocently decent though odd. Its oddity of decency is supported by three sorts of nonsense. God allpowerful becomes baby all-powerless. This powerful-powerless God commands us with his baby-needs to parent and care for him. Our neighbors are our indifferent others who are yet our own babies. All these oddities elucidate one of the contradictions in Christianity, the Incarnation in which the awesome God allbeyond man becomes a mere man.

Jesus the God-man is a supreme contradiction that spins out the above statement so odd. Amazingly, then, each turn of this statement contradicts itself so much as to throw us into nonsense. Such senseless service composes love divine to tenderly command us to obey. This command is inescapable as the parents cannot escape their responsibilities to care for the stark urgent needs here now of their babies they so tenderly love heartfelt.

Right here and now, their babies must be burped, washed, hugged, fed, and patted softly into napping, all so frequently. Babycommands are strict and absolute. No single moment can be lost. Their helplessness commands us to parent them in needs immediate, various, and meticulous. Their needs are our gods, never to be disobeyed even in the slightest, anytime anywhere.

Such incredible Christian Incarnation means for us that living close-by makes us neighbors as our own babies one to the other. Proximity means opportunity unique and timely, more powerful and efficient than distant relatives however intimate (as China says). The Incarnation makes neighbors Christ one to another (as Luther said), commanding one another with urgent needs to care for one another as caring for our own babies. Neighbors are our babies, says the incredible Incarnation that is our contradiction astounding and illegitimate. Now, what does contradiction mean?
Logic is a system of decency in thinking. Logic in society is mores that are a system of decency in society. Offending logical decency would be screamed at as logical contradictions quite illegitimate in thinking. Offending social decency is a broken taboo to be quite seriously ostracized, punishable by death, as it happened to "Woman Wang"2 of feudal China. She left home and came back, and was killed.

Likewise, Jesus Christ offended social taboos of the holy separatist group of the Pharisees, and so he was condemned forthwith to deathin order to preserve intact the walls of their social decency. But actually Christianity is a religion that purposely breaks down thinking decency into contradictions and offends social taboos of walling decent society from ugly "sinners." The result was to extend neighborly cordiality all over, among sinners now repentant received into sheer goodwill of love. China's feudal taboos also died with Woman Wang into women-liberation of China today. Breaking down walls expands togetherness so powerful so delightful.

This expansion of neighborliness is the Gospel the Good News that ushers in the New Heaven and New Earth of Love Divine, incarnate in all humanity. Love breaks down all walls of decency, while we who are purists and holy separatists scream "Foul!" totally illegitimate. Love offends decency that builds walls. They are precisely those walls that are broken down by love that cares for all. All love smells all contradictions, whether we smell so or not. Offending taboos logical and social brings death to the breaker and the social order, and then love floods all over.

Breaking down walls of decency brings in totally illegitimate flooding of neighborliness that now keeps spreading from this neighborhood herewith many shady unmentionable folks!- to another one there. $\mathrm{O}$ my, how could we so decent mix up with those so smelly,

${ }^{2}$ See Jonathan D. Spence, The Death of Woman Wang, NY: Penguin Books, 1978. It is a sad story in feudal China of a woman who left and came back home to be killed.

Http://escipub.com/international-journal-of-social-research/

0003 
unbeknown, unfamiliar, and so indecent? Such is the smelly love of free neighborliness so illegitimate! This is how "I must love my neighbor as myself." This is one great command of love side by side with the supreme command to love God with all my heart, all my mind, and all my soul.

No distance in decency, in culture, in language, in race, in age, or in anything else in the world, can ever separate the joining of irrepressible glue of loving care all powerful and all so sonorous musical. This love-music must create its own tune and its peculiar rhythm, breaking down all decency-taboos logical and social. Whoever we are, we join hands together to turn delightfully invincible. We are helplessly happy, for we cannot help but sing starlit love and care of the friendly skies miles high, forever free in joy all-joined, all so kid-happy.

Listen. Decency lies in neatly separating things and people. Rambunctious kids in all joy consist in messing up such neat separation of decency. Kids just love to mix things up, and mixing with other kids they do not even knowto play together. And togetherness is sheer joy among all kids of all ages. Togetherness cares one for the other. Togetherness is joy heavenly all mixed-up. No wonder, all august and perfect Kingdom of God belongs to the messy kids who could not care less but playing together. We must follow those messy kids. They are angels descended from up above to guide us into joy. Joy is terrific mess of illogic speculative and social.

Joy scrambles up all decency logical and social into mixed-up togetherness so powerful. Contradiction guides us on. It is not by accident that Christianity is full of contradictions. The law is made to be broken, for obeying the traffic law to its letters will kill drivers on highway. Traffic laws are to be broken with discretion, and our discretion is highway safety. Laws broken fulfill the law. The Good News lies in breaking the law of logic and of mores. Kids are here guiding us; they are the way to messy joy of breaking the law with discretion, and their discretion is playing together in joys! Contradictions with discretion of togetherness compose the Good News of ultimate joy.

But of course we cannot break the laws of decency if we have no such laws to begin with. And, on one hand, such laws come out of "law and order" needed to keep intact the society of all existence. On the other hand, however, the basic Christian contradictions derive from the twin primal contradictions of creation and God's love that creates. We are trapped in a contradiction, after all. Twist and turn as we may, the primal contradictions of homo-cosmos remain as the "rocks of ages."

And yet, "contradiction" by nature is unstable, as contradiction has to contradict something else other than itself. Contradiction depends on the uncertain other. But here in this primal realm of the ultimate, contradiction unstable is solidly stable as the ultimate is stable, and stable instability is a contradiction. Instability keeps things moving and alive. Stability shows constant existence of things staying as they are.

This unstable stability is a contradiction ultimate that supports the world. All these contradictions belong to Christian God who creates the world in his love, and both creation and love of God are contradictory, as we thought about before. Contradictions in Christianity are primal all around to compose all existence all around. Still, contradiction is fractured logical pieces. Fractures surprisingly compose the lifeworld.

\section{\#Fractured Beyond, Fractured Human:}

Breaking through our human thinking-bounds and soaring beyond us makes contradictions. Such contradictions would be found to somehow gather into a new sort of meaningsystem, or would they? We suspect that these contradictory bits and pieces would eventually somehow-this somehow is uncertain and factual-cohere into a new systematic world of actuality. Such is what is usually found to be after bloody mess of revolution political and 
theoretical. After the catastrophes, scattered debris would somehow clean themselves into a world so new as to be unheard and unseen before.

Fascinatingly, as we see things breaking up into debris mutually contradictory, we smell all contradictions pointing beyond themselves, and their mess going beyond them is slowly on their way to coagulate themselves into some sort of coherence unheard of before. In focusing on "contradictions" in this paper, we are at the pivotal transition-juncture of impossible mess on its way toward wobbly coherence. Still, we in the midst of contradictions see nothing about things in transition. All we see are a whole mess of fractured bits and pieces scattered without rhyme without reason.

This critical juncture is typified by contradictions in Christianity. In this mess, Christianity sings Creative Love of the Beyond at the dawn of new creation and its brave new world. Creative initiation is filled with fractured contradictions, for anything under construction is a mess. Likewise, our lifeworld here now is an impossible mess in fractured contradictions, as all newspapers are quite eager to report.

Our fractured contradictions here now tell us that our lifeworld is always under new construction full of messy violence and bloody fractures all around. We turn pessimistic, when our dear Pollyanna would point precisely at such scattered bloody mess and say, "The day is drawing near!" Thanks to her stubborn optimism, Pollyanna sees what we do not see. We laugh at her, and she laughs back in silent confidence.

And then, we are surprised to see such a stubborn laughable Pollyanna in the contradictions of Christianity. Christian faith also says, "When these awful things begin to take place, lift up your heads and hearts high, for your salvation draws near!" Isn't such "incredible shout" an unreasonable contradiction? Realism knots its eyebrows of pessimism. Irresponsible unrealism of Pollyanna Christianity laughs its way through thick and thin. The choice is ours. We can join realism or Pollyanna.

We can ram through contradictions that point us to all directions at random, and thrive together in love. We can also realistically hate one another-"Look how bad he is!"-and die together in mutual violence. Indifference turns us all into a desert so sandy so gritty, all no fun. Motherly love then comes over us from above to enable us to perform our choice. So we think. And yet we are surprised to find things turning out quite otherwise.

In the nonsense of these contradictions logical and factual, such nonsense opens up all sorts of possibilities, which usher in brutal revolutions that guide us into our salvation out of our fractured nonsense of mutual hatred-we profess to love our neighbors as our self, and perform exactly the opposite in killer-enmity. Factual contradictions all around us brutally shake us up into realizing our own messy contradictions existential and performative.

One most conspicuous among these factual contradictions is Christianity. Its nonsense often so deadly joins our own deadly nonsense into an astounding novel sense. This sense is our salvation out of our fractured nonsense of killer-hatred, enmity, and violence. Only the wounded doctor heals. Only the dying savior makes us alive. Christ died to make us live. What a contradiction this is!

"How does he die?" He dies by incredibly accepting us killing him in our hatred. Of course our hatred killing him is our contradiction. In love, however, he accepts our hatred and dies in our hand of hate, and this is his contradiction. And then, his death thereby saves us from our killer-hatred that kills us. And this is contradiction of ours combined with his. Such nonsense all around! Such contradiction of love joined with hate! Only the dying savior turns us alive, indeed. Dying savior is wounded doctor to death-to live all over for us all to live all over. 
Of course, all such contradictions going around make our heads spin all around. This theoretical vicious circle spinning us insane actually spins out a beneficial circle of hate into love and out of death into life together jumping so happy. Of course such love-salvation spun out of hate-condemnation is a contradiction in Christianity, for how could love be spun out of hate, and life out of death? Contradiction for contradiction, contradiction initiated from beyond above contradicts us-all here now, to spin us out of death into life. This is love paradoxical, totally senseless.

Still, while we think that the Beyond in its contradiction as above makes no sense, we totally forget that our killer-hatred makes no sense at all, either, and we are still all constantly living within such nonsense day in and day out. And it is to our nonsense-living that the Beyond in all its nonsense graciously comes down. The nonsense Beyond alive nonsensically responds to our senselessness so deadly.

The Beyond in nonsense alive heals our human nonsense so deadly. Such a match of heavenly nonsense with human earthly one is a contradiction that describes contradictions in Christianity. This match is incredible and much more than fair. Just think. In our world full of reciprocal tit-for-tat hatred, how could we have even imagined such matching of our hatred with motherly love beyond? We call all this match "sheer grace," which is a surprise gift from above.

"What is this gift?" Again we must repeat. Only the wounded doctor heals. Only the dying savior makes us survive our sin. Hurts heal. Hurting care hugs us who hurt the care-with its nail-pierced hands of care, pierced by our irrational hatred in absolute nonsense. We cannot help but kneel down in awe-filled gratitude, as intoned by innocent Mozart, hugged by God's grace.

\section{\#Are Contradictions Senseless?}

"You my dear poor friend have been trying so desperately hard to take these contradictions as nonsense of profundity. But aren't they just pure nonsense of all nonsense? How can you tell nonsense of plain nonsense apart from nonsense of parental love so precious?" Wow, my dear friend! You have just raised a crucial stumbling block on which crumble into pieces, in ridicule, all our long-faced serious discussions on Christian contradictions as something important. What if all this discussion is just rubbish, all such nonsense ready to consign to the wastebasket? What is it that prevents us from doing so? All this is so embarrassing!

Well, frankly, I do not know how to respond to such honest devastation. This ignorance may be another bothersome "contradiction" constitutive of Christianity, but this time we cannot afford to leave it at that. It is so groundshaking of this whole paper as to demand some probing meditations on it. Gazed at carefully, the above query appears to amount to a pursuit of distinction between sensible nonsense and senseless nonsense. In other words, we want to know how to tell sense apart from nonsense.

The fact is this. We do somehow know that there is definitely such a critical line. This is the line that separates being civilized from being uncouth, being a mature adult from being a raw child, and being a sensible artist from being a vulgar plebeian. Significantly, it is education that induces the realization of this line, and significantly, human children can be taught on this line, while animal babies cannot.

The point here is that we do know that there exists such a line, and yet we do not know how to say it. Definite and inexpressible, this line is so spooky though so indispensable. We the civilized persons are stuck here in this stumbling block of civilized sense. You my pal have sensibly asked for how to distinguish sense from nonsense, and we all know the importance of their distinction, and even know on how intuitively to distinguish them-it is what makes us human!-and yet we are forever Http://escipub.com/international-journal-of-social-research/

0006 
short of words on how clearly to articulate the distinction and express in words how to perform the distinction.

Now, let us go a step further. We have stressed the importance of sensibility that distinguishes significant nonsense from nonsensical nonsense. In Christianity, this sensibility is "faith" that is human acceptance of divine acceptance. When we have faith, we would understand that all contradictions, human and divine, introduce us to the infinity of the Beyond, caring friendly and parental, and sheer unexpected grace from above. When we have no faith, all Christian contradictions are mere broken thinking-pieces scattered and senseless, fit to be thrown into a basket.

"But then, how do we proceed on 'faith'?" It is simple. We hear of Christians keep proposing to the world an outline of the Good News, such as said at the beginning of 1 Corinthians 15 . The Acts of the Apostles record how such Christian mission fared to give birth to the young church. On hearing such Good News, we can of course take this proposal as a clever myth with tons of contradictions.

We entertain such a myth, and then set it aside and forget about it. Our world will go on as before without a dent. All this while, we see so many contradictions at the base of Christianity that we do not know what "Christianity" is. We laugh at "bad Christians," and leave them alone. They are none of our business, of course. But they are our ready rebuttal to those crazy Christians who propose "Christianity" to us.

We meet insane contradictions that turn Christianity senseless. We meet unsavory "Christians" to shame what they profess as Christianity. We would say, laughingly, "So, what else is new? You are proposing another strange 'religion' just as good and just as bad as any other. Bad apples are in your Christian barrel as there are in a Buddhist barrel." We play the know-it-all bystanders, as if "Christianity" is none of our business.
Christians can make all the noises they want. We go our way of managing life.

Or else, we can take into our hearts and souls such Christian proposal-Christian mission of love-in utter seriousness. We accept heartfelt Jesus Christ's offer of deathly acceptance heartfelt. Jesus then appears in his stark presence. "Presence" is usually invisible. We simply feel the presence of my friends and my parents-silently caring for each of us. And we now realize. Their presence is actually an extension of Jesus present behind them and within them. We feel him in me when we feel them to me. We, they, and he melt into one in me. To live is Christ.

And then, strangely, an event, in fact, any event, would come to tell of this love friendly and parental, all heartfelt. This love in these events comes to hug me with his nail-pierced hands, pierced by my senseless hatred of him. He clearly loves me. I often see him - or rather feel that I see him-my Jesus. He silently stares at me with eyes brim-full of tears. I ask him, and he nods. I clutch to my bosom the Lord's Prayer he taught me, again and again. My Jesus and I live one in two, two as one. To live is Christ.

"To live is Christ" is quite special. Whenever I hear of "bad Christians," I think of myself. I often ask Jesus, "Why do you still love me such a bad boy?" And he would smile and say, "It is because you are bad that I love you, my dear boy. If you are good, I need not love you, I will just use you, right?" This is love so paradoxical as to make me kneel down in sheer gratitude.

Diogenes was reputed to roam around the marketplace with a lit candle in broad daylight. Asked what he was looking for, he would say, "I've been looking for a bad man, for everyone says he is good." Precisely the opposite is the situation in the Christian world. Here there is not a single good guy. Everyone in Christianity is a bad Christian. We are all forgiven sinners. That is why we are so happy. 
Mind you. Confessing that I am bad is sheer pain. That was why Diogenes had to search a bad man. But, to confess me bad and to be forgiven-no confession, no forgiveness is possible-is sheer joy. This joy has not come easy. This joy is purchased by the sinless Godman Jesus becoming sin to die for us. Such joy of being a forgiven sinner is contradiction manifold. The great Saint Paul says he is the greatest of sinners.

All such contradictions now appear as nothing but sheer bliss. Naturally, forgiving others relaxes me at ease at home in me. And then, I instinctively reach out to care for others I meet, just as he cares for me. All enmity vanishes. And then, I find myself praying for them as I beg Jesus to forgive me, night after night. All contradictions, mine and his, only deepen my awed intimacy with my Jesus so warm so embracing, as my Jesus tenderly calls me, "my Kong-bêng." All this describes the itinerary of a smallest one of Christian pilgrims. This paper adumbrates all this.

We have just described an enormous worlddifference resulted from the choice between casually begging off an invitation from Christians, on one hand, and whole-heartedly accepting Jesus' heartfelt life-invitation, on the other. The choice here is entirely different from a theoretical and objective choice, where the person who chooses does not move but stays above the situation to survey the whole factual situation in panoramic fairness.

This choice on Christianity is a religious one, where the entire person is involved and changed, to change the entire world. "What is it that tells apart sense from senseless in Christianity?" It is a choice that involves the entire person. The person must decide to begin with, and then she would realize the sense-senseless difference. The person would never know the difference until after the choice on Christianity is made in personal commitment, pro or con, quite decisively.

The choice is the choice of personal commitment. The choice is to choose whether to commit oneself to this ultimate Beyond, or to that. How we can tell the difference of any sort comes after the choice in commitment, never before it. This is the peculiarity of religious choice. Religion does not allow an objective, balanced, and informed choice as with all other choices in living management.

Religion is a brutal tyrant that reigns over the entire person. This tyranny comes from religion being concerned with ultimate concerns. In the realm of ultimacy, commitment to a specific world of personal experience is unconditionally required. Naturally, all sorts of contradictions arise (no balancing survey allowed) to attend religion, especially in Christianity in absolute God and universal love. Naturally, such religious contradictions deepen religious significance, and never dilute it.

\section{\#Love in Pain:}

"Bad Christians have been explained, rather surprisingly. Now, what do you say about pesky senseless contradictions in Christianity?" Well, Christian contradictions are awesome, as love so precious is pretty not at all. An explanation is in order. Love suffers long. Love is served by pain in death and hell. Pain deepens, augments, and develops love. Contraries complement, as joy of love is enhanced by love suffering pain.

In love, braving pain, defying pain, accepting pain, and undergoing pain are all melted into one. Love is strong as death in pain. Love is ferocious as terrible hell. All of them are all at one, tender and terrifying, both at once. They are contraries demolishing one another, and all this while, they support one another, strengthening one another in intimate interdependence. One cannot exist without the other while one is destroyed by the other. Both inter-destroy as they inter-enliven. Such contradiction is embraced in love almighty and all-comprehensive. In fact, such contradiction constitutes love as such. 
Love gathers into itself all inter-slashing contraries into inter-supporting indispensable components one of another. Love is such contradictions alive to enliven the whole hosts of devastating enemies and turn them into bosom supporters. Such gathering and loving transformation cost enormously to those who gather, however. Death results from this daring gathering of mutual enmities. Contradiction contradicts many contraries to death. Death in this context is the glue that glues what by nature can never be glued. Christianity lustily chants this glue of death as "the cross is the crown" of love invincibly gluing.

Love is such supreme contradiction that awes all those involved down on knees, in reverence heartfelt. Contradictions of love with enmity and their gathering into inter-support indispensable, such contradictions spell love alive all over always. After all, contradiction contradicts, and contradicting activities constantly move on, quite alive. These Christian contradictions are constitutive of the Christian Good News_-of love alive in suffering pain without ceasing.

Love constantly comes and cares. Care suffers pain. Such indissoluble chain of love, care, and pain is what the English language tells us. ${ }^{3}$ Wondering about all this turns into awed wonder at all this. We wonder alive at the why and the how of all this contradictory joy in pain. As we wonder, our wonder turns itself into sheer wonder, all awed, at all this joy-in-pain so contradictory, mutually opposed to reciprocally enhance.

In all this warm reverence of paradoxical love, we must firmly keep in mind that love so precious is pretty not at all. Love as caring is all-pain, all bloody tragedy. Loving cares are often rewarded with brutal execution, for love contradicts, and contradiction kills. Again, love is sheer pain, never pretty. It is never pretty,

\footnotetext{
${ }^{3}$ Love by nature cares even in language. On the linguistic connection of "care" and "pain," see The Oxford English Dictionary, Second Edition, Clarendon Press, Oxford, 1991, 2001, II; 893-894, and so on.
}

never rosy, never casual and happy-go-lucky. This fact is of course a straight contradiction, for we would have expected love to be rosy all around. Love is a sheer contradiction.

Furthermore, braving the pain of love and still continuing to love and care for others, is an unintelligible bravado, quite beyond naïve Pollyanna stubbornly optimistic. We doubt if such a Pollyanna can even understand such further contradiction of love in lethally painful caring (first contradiction) that dares to continue (second contradiction). If this duplication of contradictions does not awe us, we are not human. If such Christian contradictions do not impress us heartfelt, we are bestial, even below the level of innocent animal.

All this while, love keeps coming to care, and caring suffers. The scene is not pretty and it is so priceless. We embrace this contradictioncare suffers, not pretty here is priceless-in sheer awe and reverence. And those who but understand such awesome height of love would be overflowed into caring for others, no matter what the situation is, and however who the others are. Love in pain has no respect of persons.

"Take, eat. This is my body, broken for you." Just like that, so bodily intimate, so eagerly loving us. We are each invited to feast on his total life so precious so not-pretty. Love invites me in person to feast on its life total and entire. All this feasting on life is such an ugly pain and so priceless, and all so precious and beautiful in all its ugly intimacy. Feasting on life constitutes love in pain. Love is deathly pain into us, to spread to us absolutely unworthy. Our unworthy life is then embraced totally into his total love in total caring life. And then, we ourselves are changed into his love. Love in pain changes us totally into his love and his life. To live is Christ, indeed.

We in Christ are now all too eager to serve and to care for whoever we meet on our way of living. Persons on the way are persons in caring way. The love that stubbornly keeps caring is beyond common sense, for we should Http://escipub.com/international-journal-of-social-research/ 0009 
have given up long ago. Such stubborn paradox composes paradise of heaven on earth. Love-paradox is paradise above, incarnate here now on this soiled earth.

All such stubborn love culminates in caring pain to compose contradictions of paradise up above, now descending to pervade down here all over. Pesky contradictions to our mind and intellect are now awesome contradictions of love so precious in Christianity, treasured by us all. Such is the great Christian contradiction behind all contradictions that constitute Christianity.

Once we grasp this root-contradiction, we would be completely grasped by this lovecontradiction of love-paradox. We would now usher in a second Pentecostal hoopla, repeating the first one reported at the beginning of the Acts of the Apostles. We would be those extended apostles continuing those acts of those apostles. The joy in such pain of love is incalculable and inexpressible.

Love particularizes as justice universalizes. Love focuses as justice spreads. One is contrary to the other as one is complementary to the other as they inter-embrace to interinvigorate. Still, these intimate contraries can tend to clash one into the other. How such conflicts take place makes up the tragic tapestry of world history and personal histories. This is how our lifeworld is constituted. It is remarkable that the eternal contraries of love and justice inevitably appear concretely as the tragic world history.

The eternal love in all its justice must then be en-fleshed into humanity to partake of human tragedies. It is thus that this Incarnation of just love eternal then loosens up knotted entanglements of clashes of love and justice. In other words, these tragic conflicts ultimately stem out of love and justice as contraries. All these knotted troubles are what have been dubbed as "contradictions in Christianity." These contradictions concretely appear as the drama homo-cosmic of "sin and salvation."
This drama is also dubbed as a contradiction in Christianity.

The wonder of wonders is that all this happens in a twofold way. First, the watertight logical death-trap in either horn of the dilemma has actually been contrived by insidious ill-will to harm many parties involved. And then, secondly and amazingly, "just love" manages to transform the deadly neither-nor dilemma into both-and well-beings of all parties concerned, both attacker and attacked. Here is just one instance in the Bible that is filled with such astounding examples. If contradictions are the spices of life, then love-resolution of such contradictions is the most fabulous spice that enlivens life a thousand-fold. Here is one stunning instance, casually recorded in John 8:1-10.

A crowd of people led by a clever priest put an adulteress in front of Jesus, and asked him, "This lady was caught in the act. Moses' law says she must be stoned. What would you say?" It was an obvious logical trap. If the answer is "Yes, she ought to be stoned to death," they would say, "Aha, Jesus is not merciful." If No, then they would say, "Aha. Jesus disobeys the sacrosanct law." Still, this trap that manipulates the law in order to harm Jesus and others is effective because of the ultimate clash between law and mercy, between love and justice. Couched in iron-clad logic and law, no one seems to be able to escape this deadly dilemma.

Jesus was silent stooping, scribbling stuff on the sand. Continued to be pressed for an answer, Jesus stretched up, casually said, "All right. One who has no sin can cast the first stone," and stooped down again, scribbling again. Wow, confronted with this "permission," people turned hushed, and the priest was the first to steal himself away, followed by his followers, one after another. In the end, the lady was left, stood alone. Jesus stretched himself again, and said, "Dear lady. Is there any one condemning you?" "No one, Sir." "I 
will then not condemn you, either. Go, and sin no more." All is silent.

Sharp drama indeed it was. No one was hurt, not the lady, not the law, not the crowd. Jesus was calm among them. He saved them all! All this result was due to his simple permission, "Anyone sinless can cast the first stone." This permission fulfills the law, but it is impossible to uphold in this case. The very fact that people came with the adulteress to see and ask Jesus at all shows that they are disqualified to cast a stone.

People came with ill-will to harm Jesus (which is illegal) by using the law (which is illegal as well). Their coming over at all this way disqualifies them from being "sinless." They had to leave Jesus, leaving the lady not-stoned. But what did Jesus do with the sins of the lady and of those people? With Jesus' stunning intelligence of loving them all, he then silently left them to die for them all to atone for their sins-and then live again for them in perfect joy all spread out in justice. The result is all joys all around, indeed. Not only did Jesus turn their ill-willed traps moot, Jesus saved them all in his love, with the law intact.

Again, wondering at why of all this joy now turns into sheer awed wonder at all this joy. Far from resenting contradictions, we are now elated beyond measure, as we embrace to our bosom such contradictions, ecstatic beyond all our dreams. We cannot live without such subliminal contradictions at our roots. Christian contradictions are precious not-pretty, beautiful so bloody, and awesome so sublime. Nothing is comparable to such ineffable joy in pain of caring love so stubborn so persistent, world without end. If this is not New Heaven and New Earth here now, there is no such.

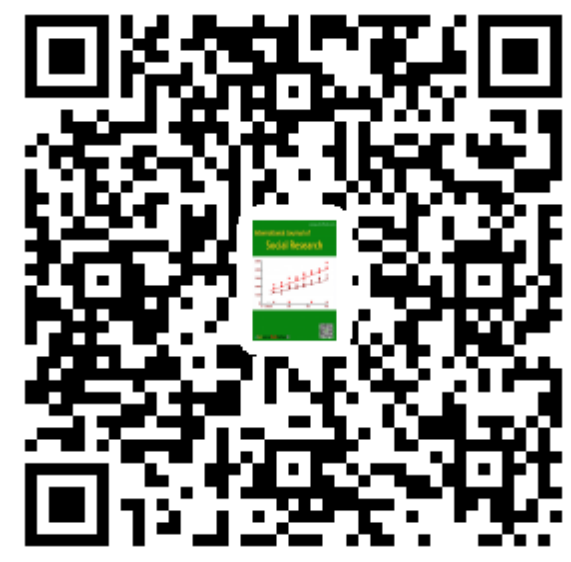

